\title{
The Effect of Humanitarian Engineering on Female Learning and Confidence
}

\section{Ms. Tara Gupte Wilson, The Ohio State University}

Tara Wilson is a graduating undergraduate student of Food, Agricultural, and Biological Engineering at The Ohio State University. For the past six semesters, she has worked as a teaching associate for OSU's fundamentals of engineering honors program - a first year, introductory course required for all honors engineering students. She also spent two semesters working as a teaching assistant for the Food, Agricultural, and Biological Engineering Department's thermodynamics class. She worked in a chemical engineering laboratory for four semesters studying separation of human red blood cells from whole blood. After that, she spent four semesters studying engineering education, resulting in four publications. She also volunteers at a free clinic called Physicians Care Connections, the Dublin Food Pantry, and Sandlot Children's Sports Camp. This fall she will begin her masters in Biomedical Engineering at Wright State University.

\section{Dr. Derek Breid, Saint Vincent College}

Derek Breid is an assistant professor of Engineering at Saint Vincent College. His interests include integrating active learning techniques into classic engineering courses, and studying the mechanical behavior of soft materials.

\section{Dr. Ann D. Christy P.E., The Ohio State University}

Ann D. Christy, PE, is a professor of Food, Agricultural, and Biological Engineering and a professor of Engineering Education at the Ohio State University (OSU). She earned both her B.S. in agricultural engineering and M.S. in biomedical engineering at OSU, and her Ph.D. in environmental engineering at Clemson University. She worked for an engineering consulting firm before entering academia and continues to collaborate with the consulting industry. She has taught courses in bioenergy, biological engineering, capstone design, HVAC, thermodynamics, waste management, professional development, and engineering teaching. Her research interests include energy, the environment, and engineering education. She is assistant dean for teaching and learning in the College of Engineering. She is a second-generation woman engineer.

\section{Dr. Clarissa Belloni, The Ohio State University}

Clarissa Belloni is an Assistant Professor of Practice at The Ohio State University, teaching courses in mechanical engineering and supervising student research in the Hydro and Aero Energy Group. She is an IEC subject matter expert developing industrial standards for hydrokinetic resource assessments. Her previous industry positions include Head of R\&D at a German start-up company, developing hydrokinetic river turbines for rural electrification and as an energy research specialist at GE Global Research Europe. She is a graduate of both the University of Oxford and the Technical University of Munich. She is an Author and co-author of publications and patents in the fields of applied fluid dynamics and thermodynamic processes, as well as engineering education. 


\title{
The Effect of Humanitarian Engineering on Female Learning and Confidence
}

\begin{abstract}
There is a growing field within engineering education research that focuses on the application of engineering skills to solve problems experienced by low socio-economic, marginalized, or under-served populations. One benefit of implementing these humanitarian engineering programs is that this may be a way to improve retention of women within engineering. Humanitarian courses, including humanitarian engineering senior design capstones and servicelearning study abroad programs, have higher enrollment of women than their traditional counterparts. Analyzing the motivations of participants in these programs reveals that women gravitate towards projects that allow them to become a "global professional" and "make a difference" while men want to "make a difference" by working on "exciting immersive realworld projects." Thus, women seem to prefer projects that make a difference to other people while men choose work that they personally find to be exciting. However, within the existing research, there is little that explores the impact of these projects on the learning outcomes of women.

This study compares the academic performance of women in a junior-level thermodynamics course in two different engineering disciplines (biological \& agricultural engineering and general engineering) when the course includes a service-learning project versus performances in traditional thermodynamics courses (in chemical engineering and mechanical engineering) with no additional humanitarian project work. Surveys were given to students in the two project-based thermodynamics classes from different universities to assess their perceptions about how well they learned the course material. Additionally, the aggregated grades of male and female students across all four courses were compared to determine if student grades reflect a difference with the addition of a humanitarian engineering project. The goal of this study is to better understand whether humanitarian engineering projects may be used to improve the motivation, retention and educational outcomes of female engineering students.
\end{abstract}

\section{Introduction}

Historically, there has been a discrepancy in engineering between the retention rates of those students who identify as male versus those identifying as female, with women earning $21.9 \%$ of all engineering bachelor's degrees [1]. Different engineering disciplines have been more successful in increasing representation of women than others, specifically in the fields of environmental, biomedical, and biological \& agricultural engineering which graduated 50.6\%, $45.4 \%$, and $42.1 \%$ respectively [1]. A participating university in this study, the Ohio State University, has the second largest undergraduate Biological and Agricultural engineering enrollment in the U.S., with 362 enrolled overall (2018-19), and it ranks near the top for highest percentages of female faculty (41\%) and female undergraduate students (47\%) which is higher than the average, even within the biological and agricultural engineering discipline.

The introduction of humanitarian engineering (HE) programs has served to attract and retain women at a higher rate than other engineering programs [2]. These HE programs can vary widely 
from service-learning projects in engineering science courses like that found at The Ohio State University, to humanitarian-based senior design capstones at the Colorado School of Mines, to Humanitarian Engineering minors at Oregon State University and The Ohio State University; however, they all use engineering skills to address global inequities [3] [4].

The use of humanitarian engineering to improve female retention is well documented, and there has been research to discover why this phenomenon exists by exploring the different motivations of men and women in engineering; one study found that the main motivation for women in HE was to 'become a global professional' and 'make a difference' while men aimed to 'participate in an exciting project' and 'make a difference' [2]. These survey answers indicate that these projects may be useful in motivating women in the engineering work they do. However, another problem with improving female retention is a relative lack of confidence compared to male peers about their perceived ability to use their engineering education in industry or for research. According to a group of MIT researchers, women in college leave engineering primarily because of a lack of professional role confidence, or confidence in their ability to fulfill the roles and competencies of an engineer [5]. One way they proposed to solve this problem was the use of real-world engineering projects, so students can apply their newfound expertise [5]. This use of project-based learning is well studied as a method of improving students understanding of content. Including a combination of project-based learning and humanitarian engineering within engineering-science courses may be a way for women to both apply their engineering skills to real-world problems and improve their professional role confidence in a setting they already find motivating and supportive.

Objective of this project: Given that including project-based learning (PBL) in engineering courses improves women's professional role confidence, there is possible benefit to including HE inspired PBL in engineering science courses to improve women's perceived understanding and possibly their actual ability. This paper compares the average grade of women against men's average grade and the class average in thermodynamics courses at a large university (The Ohio State University, Columbus, $\mathrm{OH}$ ) with the humanitarian project, the same large university without the project, and a small college (St. Vincent College, Latrobe, PA) with the project. Open-ended student responses of participants in the project were analyzed to study student attitudes about how they performed in the course, their confidence with the material, and the effect of the humanitarian engineering project.

\section{Methods}

Context of the Project: The project focuses on food insecurity [6]. One problem at the local foodbank's mobile produce markets is that clients stand in the summer heat for hours waiting in line. Food is delivered via refrigerator truck, but once unloaded, often into an empty blacktop parking lot, it can be a challenge to keep produce and the occasional perishable items at proper holding temperatures for the four to six-hour duration of the food distribution event. A solution is needed to keep people and produce cool. Stakeholders include clients, volunteers, the property owner, nearby property owners, the foodbank, and donors. Students discover the needs of these multiple stakeholders and propose cooling device designs that could meet those needs. The sponsor for the biological and agricultural engineering course project was the MidOhio Foodbank, a large regional food bank; the sponsor for the general engineering course project was Westmoreland County Foodbank, a local county food bank. 
Thermodynamics PBL assignments: This project included six modules with six associated student deliverables spread over one semester:

1. Concept map exploring connections between energy and (a.) poverty, (b.) food production, processing, and distribution, and (c.) the environment (group assignment, each group picks one of the options)

2. Preliminary documentation of clients' needs, characteristics, and perspectives. Includes discussion board participation, interview results, on-line and in-person research (individual assignment)

3. Preliminary decision matrix memo documenting 6 different user perspectives (group assignment)

4. Jigsaw assignment where team representatives investigate different cooling technologies and report back to their teams, (e.g., Refrigeration vapor-compression system, Evaporative cooling system, Thermo-electric cooling, Thermo-acoustic cooling, Cryogenics, Super insulation, and other creative designs) (group assignment)

5. Conceptual design memo documenting three different designs to meet needs and create value (group assignment)

6. Final decision matrix poster focusing on one user perspective from the three designs documented in the previous assignment (group gallery walk, stakeholder randomly assigned).

Assessment Methods: To determine if women's grades are more closely represented by the class average after the integration of a humanitarian engineering project, the average final grade of women taking thermodynamics in a variety of settings was compared to the final grade of men and the overall course average. Data were collected for men and women in a biological and agricultural engineering thermodynamics course (FABENG) at the Ohio State University with the project in autumn 2019, a chemical engineering course (CBE) at the same large university without the project taught in autumn 2018, and a mechanical engineering (ME) course at the same large university without the project in autumn 2019. This assessment was also done for a general engineering course (ENGR) at a small college, St. Vincent's College, with the project, taught in autumn 2019. The frequency of grades within these courses was compared with a ChiSquared test using an $\alpha$ value of 0.05 .

The CBE course taught a lecture-based class with online homework and exams throughout the semester. The ME course includes a semi-flipped classroom with pre-lecture videos and in-class problems preparing students for the homework sets and midterms. It also included a group project researching renewable low heat energy sources to power a simulated refrigeration system, this was a much smaller scale than the HE project and did not reference any stakeholders or user needs. Both the FABENG and ENGR courses included the project in-class, in addition to their normal lectures, homework, and exams. This was accomplished by removing some previously taught material, specifically exergy and some modifications to Rankine cycle applications. 
Table 1: Summary of Each Course's Project Status

\begin{tabular}{|l|l|}
\hline Engineering Discipline & Project Status \\
\hline $\begin{array}{l}\text { Biological \& agricultural engineering, large } \\
\text { university (FABENG) }\end{array}$ & Included humanitarian engineering project \\
\hline General engineering, small college (ENGR) & Included humanitarian engineering project \\
\hline Chemical engineering, large university (CBE) & $\begin{array}{l}\text { Did not include humanitarian engineering } \\
\text { project }\end{array}$ \\
\hline $\begin{array}{l}\text { Mechanical engineering, large university } \\
\text { (ME) }\end{array}$ & $\begin{array}{l}\text { Did not include humanitarian engineering } \\
\text { project }\end{array}$ \\
\hline
\end{tabular}

Including all the classes in the dataset helps account for compounding factors like professor, institution, and class size by assessing women in a variety of settings. Data were analyzed by a Chi-Squared test to compare non-parametric samples for a paired difference. In order to test if women have a higher perceived confidence with the HE project, a survey was distributed to students in FABENG and ENGR asking about their confidence with course material. Their responses were then coded with the coding scheme found in Appendix B (Table B2) by two independent coders. The survey questions are presented in Appendix B (Figure B1). Student gender was determined for the survey using self-reported data and for grades using information from the university. The survey included 8 questions where students marked their level of agreement with statements regarding the project. Following this, there were five open-ended questions where students were asked to reflect on the project.

\section{Results and Discussion}

Course grades: Across all four thermodynamics courses, the final grades of 324 students were collected. The two courses with a HE project had a total of 114 students who participated in the HE project, and the other two courses had a total of 210 students who did not do the project. The average grade for each class, including the average by gender, can be found in Table 2, below. The grade distribution for all three courses can be seen in Figure 1, on the following page, with a grading scale for all courses in Appendix A, Table A1. The grades were normalized as a percentage of their total class; the raw data for this figure can be found in Appendix A, Table A2.

Table 2: Average Course Grades Between Three Courses

\begin{tabular}{|l|r|r|r|r|}
\hline & FABENG 3120 & ENGR 310 & CBE 3508 & ME 3501 \\
\hline Average $(\mathrm{n}=95)$ & 84.3 & 82.25 & 88.15 & 82.59 \\
\hline Female $(\mathrm{n}=52)$ & 83.5 & 80.00 & 87.94 & 85.00 \\
\hline Male $(\mathrm{n}=46)$ & 85.2 & 82.57 & 88.21 & 80.18 \\
\hline
\end{tabular}




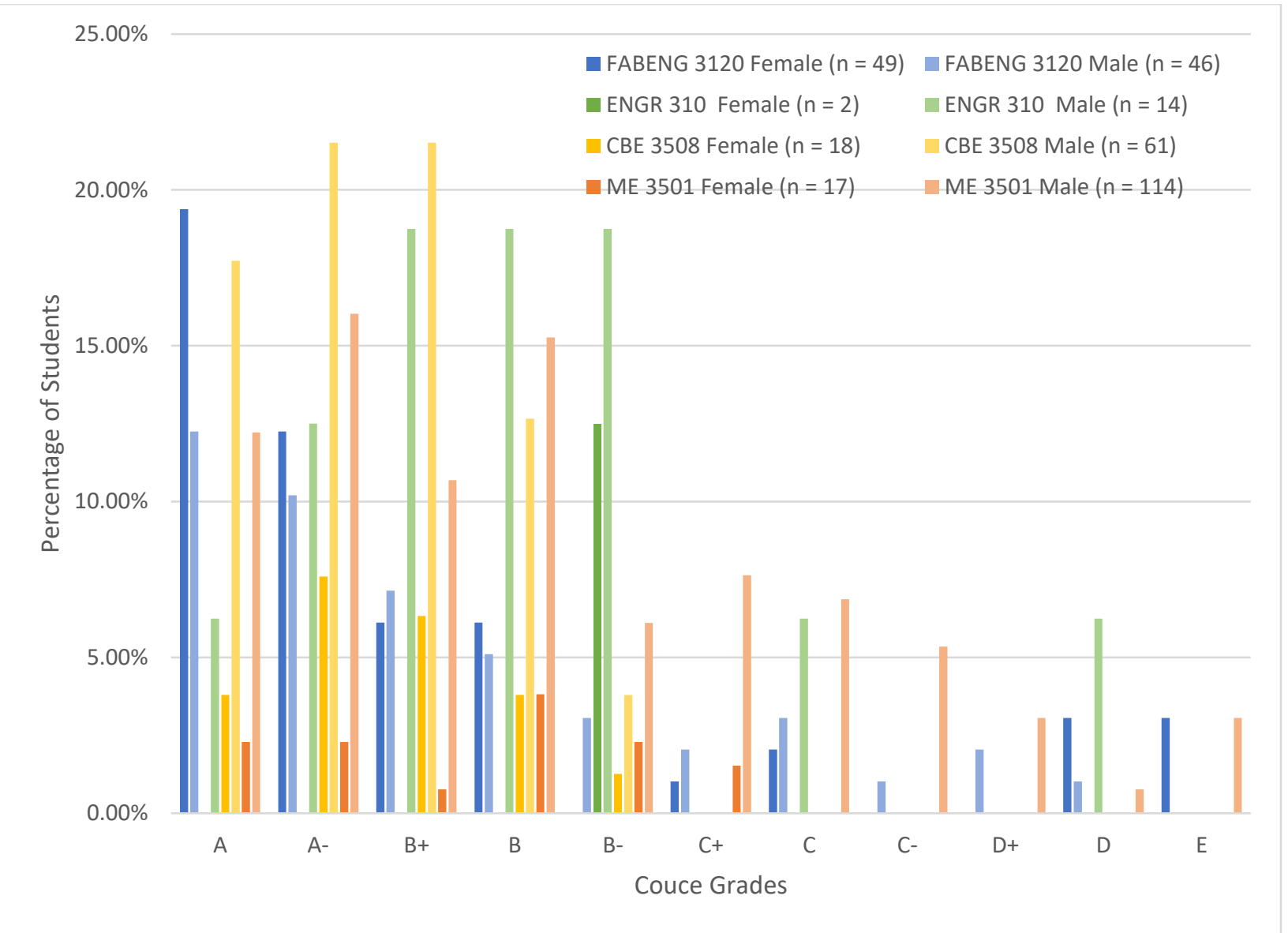

Figure 1: Student grades, as a Percentage of Their Total Class, for Three Thermodynmamics Courses

To determine if the project made a significant difference in grade distributions between gender in the three courses, six Chi-Squared tests were run, the results of which can be found below in Table 3. The tests were each set up to compare four groups; for example, one test included men in FABENG, women in FABENG, men in CBE, and women in CBE. Another Chi-Squared test was run to compare the frequency distribution between men and women within the same course, the results for which can be found in Table 4.

Table 3: Chi-Squared Values Comparing Male and Female Grades with and without HE Project

\begin{tabular}{|l|l|l|l|}
\hline & $\mathrm{X} 2$ & $\mathrm{df}$ & $\mathrm{P}$ \\
\hline FABENG \& CBE & 40.92 & 30 & 0.088 \\
\hline FABENG \& ME & 41.70 & 30 & 0.076 \\
\hline FABENG \& ENGR & 50.48 & 30 & 0.011 \\
\hline ENGR \& CBE & 37.52 & 18 & 0.004 \\
\hline ENGR \& ME & 34.35 & 30 & 0.267 \\
\hline CBE \& ME & 45.44 & 30 & 0.035 \\
\hline
\end{tabular}


Table 4: Chi-Squared Values Comparing Male and Female Grades Within Each Course

\begin{tabular}{|l|r|r|r|}
\hline & Chi squared & df & P \\
\hline FABENG 3120 & 12.1418 & 10 & 0.2757 \\
\hline ENGR 310 & 5.0286 & 6 & 0.5402 \\
\hline CBE 3508 & 0.4094 & 4 & 0.9817 \\
\hline ME 3501 & 7.62202679 & 10 & 0.665702 \\
\hline
\end{tabular}

Based on the hypothesis that the HE project would make male and female grade distributions more similar, the statistically significant difference between female grade distributions in FABENG and ME as well as ENGR and CBE, as seen in Table 5, was expected. However, the rest of the data, was unexpected. The lack of a statistically significant difference between male and female students in FABENG, ENGR, CBE and ME in Table 3, indicates that there is not a discrepancy between grade distributions within any of the courses studied which goes against the original premise of the paper, that there would be a discrepancy between male and female grades in engineering science courses, like thermodynamics. This may be explained by the ME course's use of a final project focused on designing a device to help create a low-cost refrigeration device. Additionally, CBE courses tend to have less of a problem with female retention, partially due to higher female representation within the major.

Table 5: Chi-Squared Values Comparing Female or Male Grades between Each Course

\begin{tabular}{|c|c|c|c|}
\hline \multicolumn{4}{|c|}{ Female } \\
\hline & $\mathrm{X} 2$ & df & $\mathrm{P}$ \\
\hline FABENG \& CBE & 10.75 & 8 & 0.2163 \\
\hline FABENG \& ME & 19.22498 & 8 & 0.013701687 \\
\hline FABENG \& ENGR & 54 & 8 & $6.90 \mathrm{E}-09$ \\
\hline ENGR \& CBE & 12.59 & 4 & 0.0134 \\
\hline ENGR \& ME & 6.258824 & 5 & 0.281842692 \\
\hline CBE \& ME & 7.143927 & 5 & 0.210154459 \\
\hline \multicolumn{4}{|c|}{ Male } \\
\hline & $\mathrm{X} 2$ & df & $\mathrm{P}$ \\
\hline FABENG \& CBE & 14.99 & 9 & 0.0911 \\
\hline FABENG \& ME & 8.153428 & 10 & 0.613853215 \\
\hline FABENG \& ENGR & 7.93 & 9 & 0.5412 \\
\hline ENGR \& CBE & 15.19 & 6 & 0.0188 \\
\hline ENGR \& ME & 10.68024 & 10 & 0.382966889 \\
\hline CBE \& ME & 27.96429 & 10 & 0.001829163 \\
\hline
\end{tabular}

A difference was expected between male and female students in FABENG and CBE or ME classes as well as between ENGR and CBE or ME since that compares courses with and without the project. A difference was seen between ENGR and CBE in Table 4, but one was not found between the other courses. Additionally, a significant difference was not expected between FABENG and ENGR since they both include the HE project. This difference in grade 
distributions may be attributed to the small sample size of the liberal arts college, which might also explain the anomaly between ENGR and CBE.

Student reflections: The survey (Appendix B) was given to students enrolled in two of the courses: FABENG and ENGR. Due to the small class size of ENGR, female answers were omitted to preserve their privacy. Question four used a rating scale from 0 to 100 to determine student confidence and understanding of the material. The average response for those identifying as male and identifying as females to five questions can be found on the following page in Figure 2, the data for the table can be found in Appendix B, Table B1. Question five was an open-ended request for students to reflect on how they felt they did in the course. Their responses were analyzed with four codes and the results of male and female responses can be found in Table 6 with further explanation of the codes in Appendix B, Table B2.

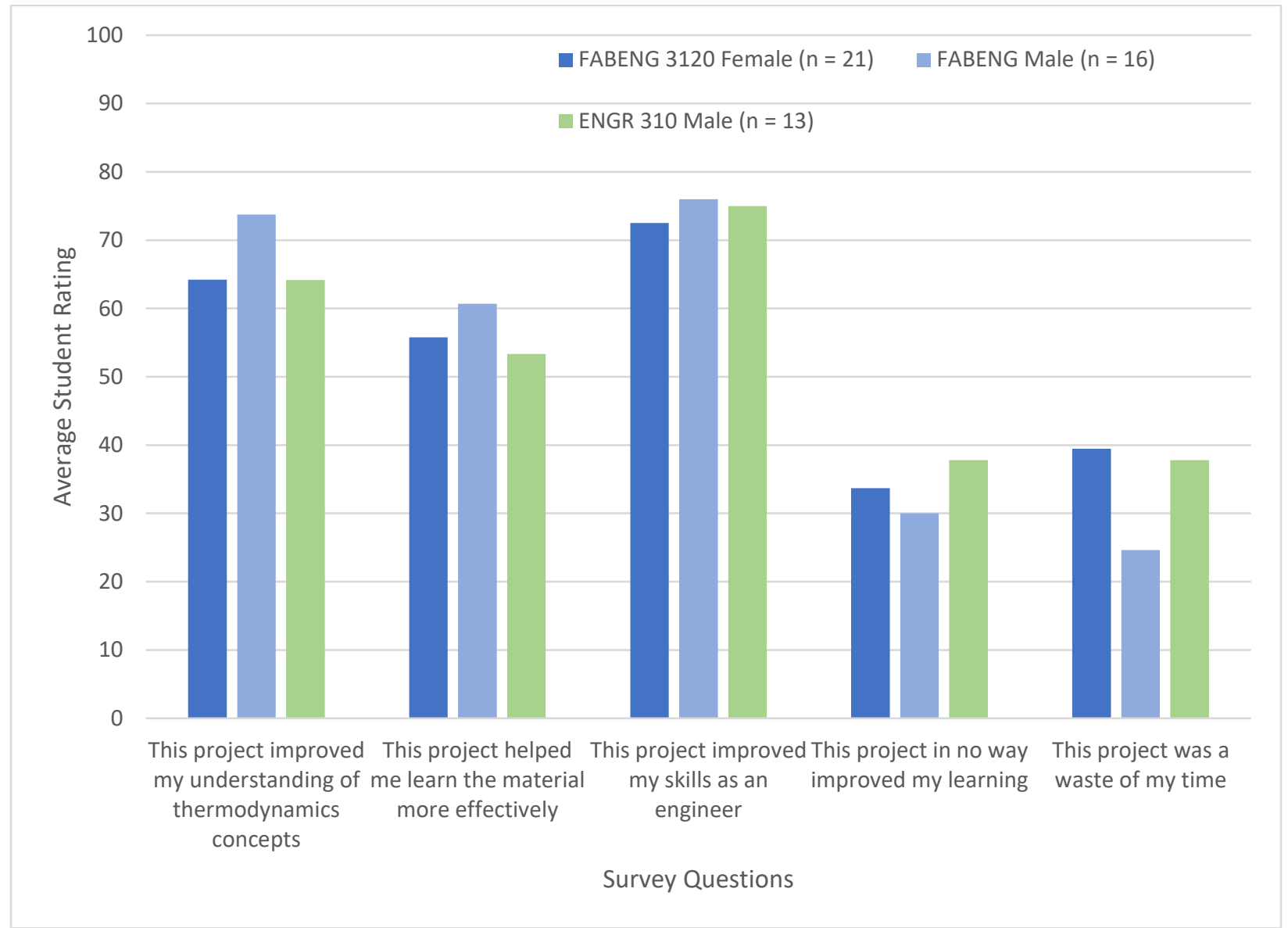

Figure 2: Average Male and Female Ratings (0 to 100) About Their Thermodynamic Confidence 
Table 6: Male and Female Coded Responses, as a percentage, to "How do you think you did in this course? Please address both your grade and how well you feel you understood the material"

\begin{tabular}{|l|r|r|r|r|}
\hline $\begin{array}{l}\text { What gender do you } \\
\text { associate with? }\end{array}$ & Did well & $\begin{array}{l}\text { Understood } \\
\text { content }\end{array}$ & $\begin{array}{l}\text { Did not } \\
\text { understand, } \\
\text { did well }\end{array}$ & \multicolumn{2}{|l|}{$\begin{array}{l}\text { Did not do } \\
\text { well }\end{array}$} \\
\hline FABENG Female $(\mathrm{n}=21)$ & $37 \%$ & $47 \%$ & $16 \%$ & $0 \%$ \\
\hline FABENG Male $(\mathrm{n}=16)$ & $19 \%$ & $69 \%$ & $13 \%$ & $0 \%$ \\
\hline ENGR Male $(\mathrm{n}=13)$ & $17 \%$ & $50 \%$ & $8 \%$ & $25 \%$ \\
\hline Total $(\mathrm{n}=47)$ & $26 \%$ & $55 \%$ & $13 \%$ & $6 \%$ \\
\hline
\end{tabular}

A difference was seen when coding for 'Did well', but that may be due to a lack of detail from those students, rather than variation in confidence. Within FABENG, 88\% of males reported positively, "Did well" or "Understood content", compared to $84 \%$ of females. Similarly, $67 \%$ of ENGR males reported positively. The small difference between male and female responses helps support the idea that there is not a difference between male and female confidence in their thermodynamic abilities in courses taught with a humanitarian engineering project.

While the impact of this project compared to a typical thermodynamics course cannot be assessed in terms of the hypothesis of this report, students did reflect on their personal growth. A majority of students, male and female, believe that the inclusion of a humanitarian engineering project improved their understanding of thermodynamic concepts and helped them learn the course material more effectively. An even larger majority of students responded that the project improved their skills as an engineer, beyond just this thermodynamics course. This study also revealed that the addition of a humanitarian engineering project was equally as effective in a large as well as a small class at improving student's thermodynamics education and confidence as an engineer.

\section{Conclusions and Recommendations}

This study aimed to prove that the inclusion of humanitarian engineering projects within engineering science courses helps close the gap between female and male grade averages. Previous research indicated that students do better in courses with the integration of projectbased learning and that women especially benefit from humanitarian projects. Based on that, students were asked to design a cooling technology for use by a local food bank at produce markets, integrating what they were learning in their thermodynamics courses.

This project was applied in a large university with a class size of 98 as well as a liberal arts college with a class size of 16. Control thermodynamics courses from the same large university had class sizes of 79 (CBE) and 131 (ME). At the completion of one semester of thermodynamics, the final course grades of all students were collected and compared using ChiSquared tests. There was not a significant difference between the courses or within the courses, which indicated that there was not a gap between male and female grades in any of the four courses studied. The survey given to students in the two courses with HE projects indicated that the inclusion of a project improved both their thermodynamics skills and general engineering skills. Future work in this area will endeavor to survey thermodynamics students who did not complete a humanitarian engineering project and compare those results to the existing data of students who did experience such a project. 


\section{Acknowledgements}

The authors are indebted to the Mid-Ohio Foodbank for their vision to create healthier, hungerfree communities. This work was supported by KEEN-ICE grant from the Kern Family Foundation. This work is also supported by Hatch project no. OHO01342 / accession no. 1003938 from the USDA National Institute of Food and Agriculture. Any opinions, findings, conclusions, or recommendations expressed in this publication are those of the author(s) and do not necessarily reflect the view of the U.S. Department of Agriculture.

\section{References}

[1] J. Roy, "Engineering by the Numbers," ASEE Dept. of Institutional Research \& Analytics. pp. 11-47, 2018.[Online]. Available: https://ira.asee.org/wpcontent/uploads/2019/07/2018-Engineering-by-Numbers-Engineering-StatisticsUPDATED-15-July-2019.pdf

[2] R. Dzombak, S. Mouakkad, and K. Mehta, "Advances in Engineering Education Motivations of Women Participating in a Technology-Based Social Entrepreneurship Program,” Adv. Eng. Educ., 2016.

[3] A. D. Christy, T. G. Wilson, and O. Meehl, "Thermodynamics for Citizenship: Entrepreneurial Engineering through Project-based Learning," in ASEE Annual Conference and Exposition Conference Proceedings, 2019.

[4] C. Skokan and J. Gosink, "Gender participation in humanitarian vs. traditional multidisciplinary senior design projects," in ASEE Annual Conference and Exposition, Conference Proceedings, 2005.

[5] E. Cech, B. Rubineau, S. Silbey, and C. Seron, "Professional Role Confidence and Gendered Persistence in Engineering," Am. Sociol. Rev., vol. 75, no. 5, pp. 641-666, 2012.

[6] J. Dubick, B. Mathews, and C. L. Cady, "Hunger on campus: The challenge of food insecurity for college students," CUFBA website, 2016. [Online]. Available: http://www.cufba.org/report-hunger-on-campus/. 


\section{Appendix A: Student Grades}

Table A1: Grading Scale for the large university and liberal arts college

\begin{tabular}{|r|l|l|l|}
\hline \multicolumn{2}{|c|}{ University } & \multicolumn{2}{l|}{ College } \\
\hline 93 & A & 93 & A \\
\hline 90 & A- & 90 & A- \\
\hline 87 & B+ & 87 & B+ \\
\hline 83 & B & 83 & B \\
\hline 80 & B- & 80 & B- \\
\hline 77 & C+ & 77 & C + \\
\hline 73 & C & 73 & C \\
\hline 70 & C- & 70 & C- \\
\hline 67 & D+ & 67 & D + \\
\hline 60 & D & 60 & D \\
\hline 0 & E & & \\
\hline
\end{tabular}

Table A2: Grade Distribution Between Three Courses

\begin{tabular}{|c|c|c|c|c|c|c|c|c|}
\hline & \multicolumn{2}{|c|}{ FABENG 3120} & \multicolumn{2}{|c|}{ ENGR 310} & \multicolumn{2}{|c|}{ CBE 3508} & \multicolumn{2}{|c|}{ ME 3501} \\
\hline & Female & Male & Female & Male & Female & Male & Female & Male \\
\hline A & 19 & 12 & 0 & 1 & 3 & 14 & 3 & 16 \\
\hline A- & 12 & 10 & 0 & 2 & 6 & 17 & 3 & 21 \\
\hline $\mathrm{B}+$ & 6 & 7 & 0 & 3 & 5 & 17 & 1 & 14 \\
\hline B & 6 & 5 & 0 & 3 & 3 & 10 & 5 & 20 \\
\hline B- & 0 & 3 & 2 & 3 & 1 & 3 & 3 & 8 \\
\hline $\mathrm{C}+$ & 1 & 2 & 0 & 0 & 0 & 0 & 2 & 10 \\
\hline $\mathrm{C}$ & 2 & 3 & 0 & 1 & 0 & 0 & 0 & 9 \\
\hline $\mathrm{C}-$ & 0 & 1 & 0 & 0 & 0 & 0 & 0 & 7 \\
\hline $\mathrm{D}+$ & 0 & 2 & 0 & 0 & 0 & 0 & 0 & 4 \\
\hline $\mathrm{D}$ & 3 & 1 & 0 & 1 & 0 & 0 & 0 & 1 \\
\hline $\mathrm{E}$ & 3 & 0 & 0 & 0 & 0 & 0 & 0 & 4 \\
\hline $\mathrm{n}$ & 52 & 46 & 2 & 14 & 18 & 61 & 17 & 114 \\
\hline
\end{tabular}




\section{Appendix B: Survey Information}

For questions $4.1-4.8$, please rate the extent to which you agree with the following statements.

Strongly Disagree (1) - Disagree (2) - Neither Agree nor Disagree (3) - Agree (4) - Strongly Agree (5)

1. This project improved my understanding of thermodynamics concepts.

2. This project made it easier for me to complete homework outside of class.

3. This project helped me learn the material more effectively.

4. This project reduced the amount of time I spent working on homework assignments.

5. This project aligned with the learning objectives of the course.

6. This project improved my skills as an engineer.

7. This project in no way improved my learning.

8. This project was a waste of my time.

5. How do you think you did in this course?

6. How does that compare to how you thought you would do in the course? Better? Worse?

7. Would you recommend continuing this project when this course is offered in the future?

a. Yes

b. No

8. What changes or improvements, if any, would you make to the MOFB project?

9. Are there any other comments you would like to make?

Figure B1: Questions Used in End of Semester Evaluations 
Table B1: Average Male and Female Rating Responses (0 to 100) to Survey Question 4

\begin{tabular}{|c|c|c|c|}
\hline & $\begin{array}{l}\text { FABENG Female }(\mathrm{n}= \\
21)\end{array}$ & $\begin{array}{l}\text { FABENG Male }(\mathrm{n}= \\
16)\end{array}$ & $\begin{array}{l}\text { ENGR Male }(\mathrm{n}= \\
\text { 13) }\end{array}$ \\
\hline $\begin{array}{l}\text { This project } \\
\text { improved my } \\
\text { understanding } \\
\text { of } \\
\text { thermodynamic } \\
\text { s concepts }\end{array}$ & 64.21 & 73.75 & 64.17 \\
\hline $\begin{array}{l}\text { This project } \\
\text { helped me learn } \\
\text { the material } \\
\text { more effectively }\end{array}$ & 55.79 & 60.67 & 53.33 \\
\hline $\begin{array}{l}\text { This project } \\
\text { improved my } \\
\text { skills as an } \\
\text { engineer }\end{array}$ & 72.50 & 76.00 & 75.00 \\
\hline $\begin{array}{l}\text { This project in } \\
\text { no way } \\
\text { improved my } \\
\text { learning }\end{array}$ & 33.68 & 30.00 & 37.78 \\
\hline $\begin{array}{l}\text { This project was } \\
\text { a waste of my } \\
\text { time }\end{array}$ & 39.44 & 24.62 & 37.78 \\
\hline
\end{tabular}

Table B2: Explanation of Codes Used to Analyze Student's Open-ended Responses, Q5

\begin{tabular}{|l|l|}
\hline Code & Rational \\
\hline Did well & $\begin{array}{l}\text { Student indicated they received a good grade in the course without } \\
\text { referencing their understanding of the material }\end{array}$ \\
\hline Understood content & $\begin{array}{l}\text { Student indicated they did well in the course and felt they understood } \\
\text { the material. }\end{array}$ \\
\hline $\begin{array}{l}\text { Did not understand, } \\
\text { did well }\end{array}$ & $\begin{array}{l}\text { Student indicated they received a good grade in the course but were not } \\
\text { confident in their understanding of thermodynamics. }\end{array}$ \\
\hline Did not do well & Student indicated that they did poorly in the course. \\
\hline
\end{tabular}

